\title{
DOPRINOS REVITALIZACIJI MIROVA - PRIJEDLOG IZGRADNJE NOVE KAPELICE
}

\author{
Martina Stjepandić \\ ARHIV arhitektura i urbanizam, d.o.o. \\ HR 10000 Zagreb \\ martinastjepandic@gmail.com
}

\author{
UDK: 728.025(497.5 Mirovo) \\ Izvorni znanstveni članak
}

Ur.: 2016-12-28

Problematizirajući pitanje revitalizacije velebitskoga područja, autorica predstavlja projekt Kapelica od Mirova - projekt smješten na prostoru srednjeg Velebita, u neposrednoj blizini lokaliteta Mirovo, koji nije sam sebi svrha već je produkt istraživanja i duboke povezanosti s Velebitom koji su na koncu rezultirali idejnim rješenjem koje uzima u obzir elemente prošlosti, tradicije, suvremenosti, a anticipira i budućnost - radi ponovnog zbližavanja čovjeka i planine, ali i čovjeka i čovjeka te čovjeka i njemu transcendentnog. Pritom ne koristi isključivo arhitektonski pristup već zagovara cjeloviti i interdisciplinarni pristup rješavanju problema revitalizacije koji stavlja naglasak na očuvanje tradicije i izvornosti Velebita i velebitskoga načina života.

Ključne riječi: Mirovo, Velebit, stanovi, revitalizacija, arhitektura, sakralna arhitektura, kapelica

\section{Uvod}

Pristup je istraživanju iz arhitektonske perspektive oduvijek bio nešto drugačiji od klasičnog istraživačkog pristupa znanstvenika drugih područja. Nesumnjivo je u pozivu arhitekta prisutan umjetnički duh koji s nešto senzibilnije strane pristupa zadanoj materiji. Gotovo je nemoguće zanemariti aspekt svojstven arhitektima koji već u tijeku istraživanja istovremeno stvaraju, ne umanjujući činjenično, nego paralelno otkrivajući nove perspektive i ideje koje u nastavku kroz projekt, nerijetko i realizaciju, generiraju promjene u prostoru čovjekova bivanja. U najboljem slučaju istraživanja u arhitekturi završavaju konkretizacijom teoretiziranoga koja na pravi način udomljava čovjeka i pruža mu potreban okvir za život. 
Istraživanje Velebita, tog gordog planinskog masiva, katkada se doima kao pristupanje neiscrpnom izvoru (spo)znanja. Ovo "vele - biće"1 primarno bogato prirodnim ljepotama i specifičnostima krajolika, nije samo prirodni fenomen već je područje u kojem su odrastale generacije ljudi, živeći u savršenoj harmoniji s prirodom. Znati kako planina živi, poznavati njezin ritam i mijene, doista je umijeće koje su žitelji ovog područja spretno primjenjivali u području pučke izgradnje. Današnje akademsko obrazovanje i potreba za svladavanjem što većeg broja činjenica i informacija, katkada nepotrebna uštogljenost i ozbiljnost u izražavanju, u suprotnosti su s nekadašnjom jednostavnošću života ovih ljudi koji su svoja znanja najčešće prenosili usmenim putem, uspješno stvarajući svoje projekte za svakodnevni život. S gradnjom se stanova u višim predjelima Velebita prvi put susrećem u razgovoru s arhitekticom Helenom Knifić Schaps, u siječnju 2014. godine, na samom početku istraživanja u sklopu pripreme diplomskog rada na Arhitektonskom fakultetu u Zagrebu.

U knjizi Velebit arhitektonski, autorica Knifić Schaps daje sistematičan pregled pučke gradnje Sjevernog i Srednjeg Velebita s opisom karakterističnosti gradbenih elemenata i principa izgradnje toga područja. Uz priložene skice i prikaze, jasno je protumačena logika izgradnje stambenih i gospodarskih objekata. Kao važnu misao vodilju i pitanje djelovanja, autorica ističe prioritet adekvatnog pristupa izgradnji novih zgrada drugih namjena u budućnosti i pravilnom odnosu prema naslijeđu u obnovi starih zgrada. "Od puno mogućnosti pristupa istraživanju pučke stambene gradnje područja Velebita jedna je i ona da se ustvrde osnovna obilježja kao temelj za revitalizaciju primjenom suvremenih materijala, tehničkih mogućnosti i estetike, uz afirmaciju samosvojnosti i identiteta, mjerila i oblikovnih osobitosti." ${ }^{2}$

Budući da je zadnjih godina starije stanovništvo gotovo izumrlo, a mlađa je populacija već odavno migrirala u razvijenije centre ili gradove, nedvojbeno je nužan promišljeni i na izvorima utemeljeni suvremeni pristup revitalizaciji Velebita. Jedino adekvatnom aktivacijom područja, povratkom čovjeka na Velebit, možemo prostoru vratiti njegovu vitalnost. Za to je potreban svojevrsni indikator stacioniranja, element u prostoru koji će transformirati i način čovjekova gospodarenja njime. To je ujedno istinska zaštita prostora Velebita - aktivacija, a ne pasivnost djelovanja, jer upravo iskrivljenim poimanjem zaštite ovog vrijednog područja doprinosimo njegovu daljnjem odumiranju.

\footnotetext{
${ }^{1}$ H. KNIFIĆ SCHAPS, 2013, 21.

${ }^{2}$ H. KNIFIĆ SCHAPS, 2013, 44.
} 


\section{O lokaciji nove kapelice}

Jedan je od većih fenomena života na Velebitu bila ljetna migracija stanovništva i njihova blaga iz stalnih naselja u stanove, nastambe namijenjene sezonskom stanovanju u vrijeme ljetne ispaše stoke, u područjima planine na višim nadmorskim visinama. Jedno od većih i bolje uščuvanih lokaliteta koje svjedoči o nekadašnjem pastirskom životu jest Mirovo, prostrani planinski pašnjak "koji se od prijevoja Veliki Alan $(1414 \mathrm{~m})$ proteže u smjeru sjeveroistok-jugozapad u duljinu od oko 2 kilometra". ${ }^{3}$ Područje je to koje se nalazi u krajnjem južnom dijelu Nacionalnog parka Sjeverni Velebit. Velikim Alanom prolazi prometnica od Jablanca na obali do Śtirovače u unutrašnjosti (19. stoljeće) i upravo se s ovog dijela ceste prostire veličanstven

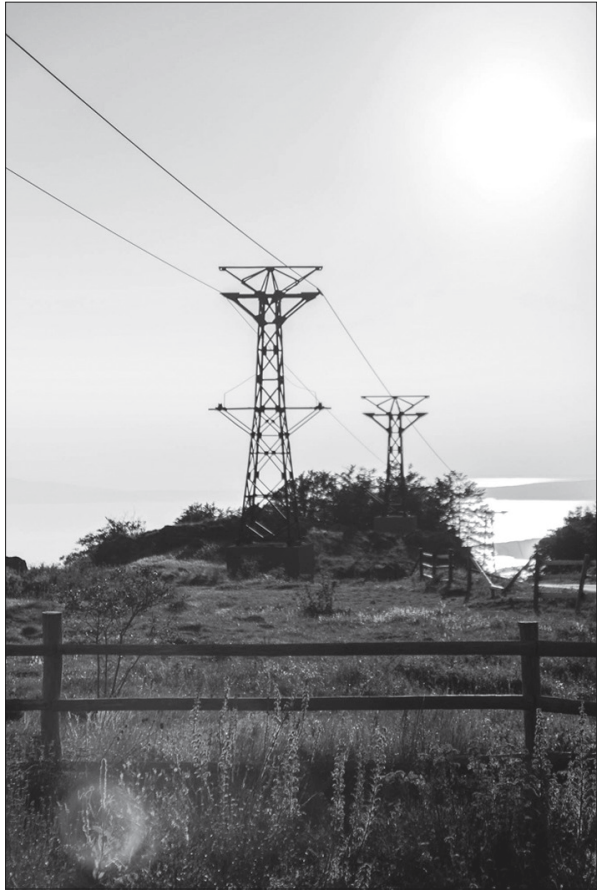

S1. 1. Napuštena žičara na Velikom Alanu, kolovoz 2016., foto: Josip Petrlić pogled na more.

Uz prilaznu su cestu vidljivi ostatci nekadašnje žičare izgrađene nakon Drugog svjetskog rata koja je služila za transport drvene građe s Velebita na obalu, a povezivala je Veliki Alan i luku u Stinici. Na transportu drvene građe radili su zatvorenici Golog otoka, koji su kroz svoj teški rad odsluživali kazne. Snažna je to memorija prostora mnogima nepoznata, koju je nužno, kao i mnoge duge specifičnosti ovog područja, na adekvatan način prezentirati te educirati naraštaje o bogatoj prošlosti ovoga kraja.

Za potrebe smještajnog turizma manjeg kapaciteta, s dovoljnim brojem parkirnih mjesta za motorna vozila, obnovljen je manji broj nekadašnjih stanova uz planinarsku kuću Alan. Od Alana u smjeru Štirovače cestom se dospijeva do Kosice $^{4}$, malog zaseoka obnovljenih privatnih stanova, uz koju prolazi i drevna vlaka Marije Terezije iz 18. stoljeća, ključan put za nekadašnje izvlačenje drvene

${ }^{3}$ A. FABER, 2013, 661.

${ }^{4}$ Š. BALEN, 1999, 73. 


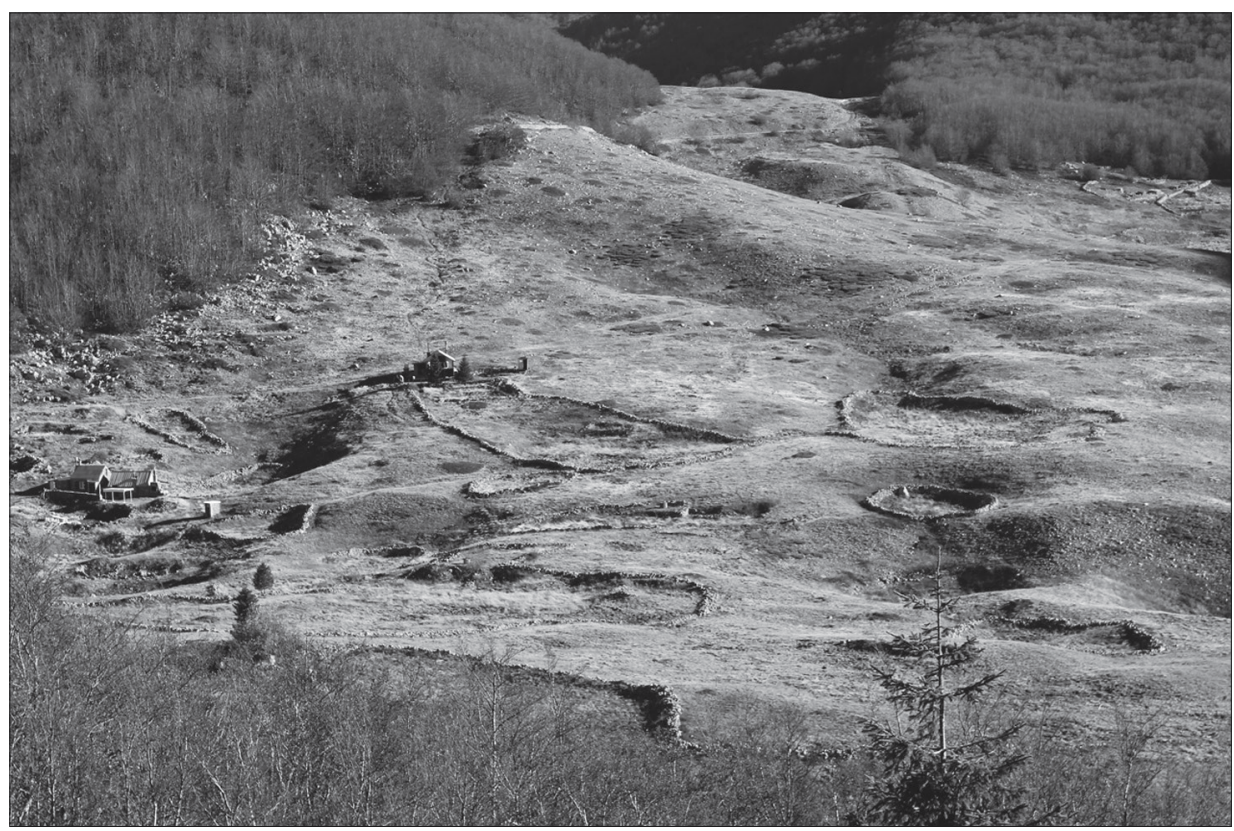

S1. 2. Pogled prema lokaciji iznad Mirova, foto: Marija Barović, 2016.

građe za brodovlje (jarbole). Cestu Jablanac - Štirovača presijeca Premužićeva staza, najpoznatija velebitska planinarska staza građena tridesetih godina prošlog stoljeća u tehnici suhozida, čiji je idejni autor inženjer Ante Premužić. Staza prolazi hrptom planine od Zavižana na sjeveru do Oštarijskih vrata na jugu i u svoj svojoj dužini od 57 kilometara omogućuje doživljaje raznolikosti krajolika Sjevernog i Srednjeg Velebita. ${ }^{5}$

Posebno istaknuto i u prostoru dominantno, bilo je područje prostranog pašnjaka Mirova (ponegdje zvanog Mireva) "zatravljenog, blago nagnutog doca (ili kose?) u kome su u to doba još postojali brojni stanovi."6 Naime, 80-ih godina prošloga stoljeća stanje na Mirovu se uvelike promijenilo. Iako i dalje poetičnog i mističnog krajolika, Mirovo biva napušteno od ljudi i prepušteno vremenu. "Vidjeti Mirovo pri zalasku sunca, kad nisko svjetlo izmodelira zatravljeni teren, poseban je doživljaj. Ostaci nekad brojnih stočarskih stanova te 1980. godine nagovještaju nekadašnji izgled i način života. "7

\footnotetext{
${ }^{5}$ H. KNIFIĆ SCHAPS, 2013, 202.

${ }^{6}$ H. KNIFIĆ SCHAPS, 2013, 202.

${ }^{7}$ H. KNIFIĆ SCHAPS, 2013, 206.
} 


\section{O sakralnoj ostavštini Mirova}

Prof. Ante Glavičić u svome istraživanju starohrvatske sakralne arhitekture na primorskim padinama Velebita navodi da se uz staru vlaku Marije Terezije, negdje po sredini Mirova, nalazila drvena planinska crkvica koja je s vremenom propala. Točna lokacija crkvice nije sa sigurnošću utvrđena i lokalitet bi trebalo detaljnije arheološki istražiti. Još su stari Podgorci svjedočili o postojanju crkvice sv. Marije od Mirova čija se svečanost održavala 22. srpnja ili 4. kolovoza, ovisno jesu li svečanosti Mirovne Marije slavili pravoslavci ili katolici. Iz istog je izvora utvrđeno kako su na ovom području boravili stari Iliri (Ortoplini i Becosi ), kasnije Romani, Morlaci i stari Hrvati. Na taj su način u doticaj dolazili poganski običaji s kršćanstvom. ${ }^{8}$

Zanimljiv je, također, kasniji međureligijski dijalog između katolika i ortodoksnih vjernika koji su u ovom rijetko naseljenom području Velebita dijelili isti prostor kapelice. Lijep je to pokazatelj kako neki specifični rubni uvjeti života, eventualne izolacije, stvaraju atipične društvene fenomene i omogućuju dijalog - kako je to Helena Knifić Schaps lijepo sročila: "Velebit nikada nije razdvajao, Velebit je povezivao."9 Ja bih tome još dodala: i neprestano nadahnjivao.

\section{O namjeni}

Pri postavljanju vlastitoga zadatka i programa diplomskog rada, bilo je potrebno definirati namjenu kojom bi se taj okvir mogao ostvariti te locus za realizaciju samog projekta. Odgovor na pitanje namjene kao indikatora vitalnosti bio je prijedlog izgradnje nove kapelice u duhu kršćanstva.

Vođena mišlju kako današnji čovjek biva sve više otuđen i odvojen od ljudi i prirode, time i nesposoban za postavljanje istinskoga kritičkog diskursa prema okolini, željela sam stvoriti mjesto susreta čovjeka s transcendentnim te naposljetku čovjeka s čovjekom u bliskom doticaju s prirodom, upravo na području Velebita. To mjesto susreta ne postaje tek samodostatni element $\mathrm{u}$ prostoru, već blagi akcent koji meko srasta s prirodom na suvremen način, pozivajući današnjeg čovjeka na promišljanje, refleksiju. Mišljenja sam da bi se realizacijom sadržaja poput ovoga, potaknulo kvalitetnije i ispravnije gospodarenje prostorom od, danas toliko isticanog, isključivo turističkog pristupa. Dakako da treba raditi i na turističkoj dimenziji, no nikako ne bi trebalo ispustiti iz vida i element stvarnoga života koji u sebi uključuje i

\footnotetext{
${ }^{8}$ A. GLAVIČIĆ, 1982, 94.
}

${ }^{9}$ H. KNIFIĆ SCHAPS, 2014. 
turizam, no tek kao svojevrsnu dodanu vrijednost, nipošto kao supstitut nestanku velebitske stvarnosti.

Jedna je od tih stvarnosti i duhovna, religiozna stvarnost stanovnika Velebita, u jednom svom obliku materijalizirana upravo u sakralnim objektima. Ranije navedeni primjer dijeljenja prostora kapelice i, na taj način, povezivanja različitosti daje dodatnu namjenu kapelici u kontekstu današnjeg vremena i nekih njegovih posebnosti. Tako bi ova kapelica, osim turističke vrijednosti, imala potencijal baštiniti i neke stoljetne vrjednote evocirajući sjećanja na neke ranije generacije i neka prošla vremena, istovremeno upućujući na sadašnjost. Dakle, iako primarno sakralni objekt, ona bi predstavljala utočište, pristanište, odmorište, odredište svakome, neovisno o religijskim osjećajima. Tako bi se njezina suvremena namjena nadogradila na namjene sakralnih objekata $u$ njihovoj prošlosti, postajući i ostajući mjesto susreta i suživota, jednog s Jednim i jednog s drugim, afirmacije i konsolacije.

\section{PROJEKT KAPELICE OD MIROVA}

Respektirajući još uvijek vidljive ostatke suhozida i stanova, za projekt nove kapelice od Mirova odabrana je nova lokacija bez istaknute arheološke vrijednosti koja se nalazi iznad ceste Jablanac-Štirovača s pogledom na Mirovo. Urbanistička koncepcija sklopa kapelice od Mirova zasniva se na križanju glavnih osi položenih u smjeru sjever-jug i istok-zapad, kao glavnih nositelja svih elementa u prostoru. Centralni dio i akcent u prirodnom okruženju čini monolit kapelice čiji se korpus usijeca u kameni teren i lebdi nad padinom. Lokacija nad Mirovom, s dvije strane okružena šumom, postaje mirna zaštićena zona, ostajući istovremeno pristupačna i otvorena prirodi.

Proplanku na kojemu je smještena nova kapela, pristupa se planinarskom pješačkom stazom u samom podnožju, koja povezuje dva kolna puta iz smjera jugozapada te sjeveroistoka. Okomito na stazu odvaja se zaseban put te je omogućen pristup lokaciji blagim usponom. Prilazni je put posut drobljenim kamenom s blagim stubama građenim u tehnici suhozida kako bi se spriječio odron materijala u podnožje. Na putu prema uzvišenom dijelu s kapelicom, postupno nam se otkriva masivni betonski monolit. Iako dominantna, kapelica i dalje ostaje neotkrivena, nepoznata i tajanstvena. S prostora pristupne platforme - narteksa, moguće je sagledati okruženje, percipirati različitosti te dati prednost onome elementu koji je prvenstveno okupirao našu misao, ne odvraćajući pažnju od prirode s kojom je ovaj sklop u neprestanom dijalogu. 


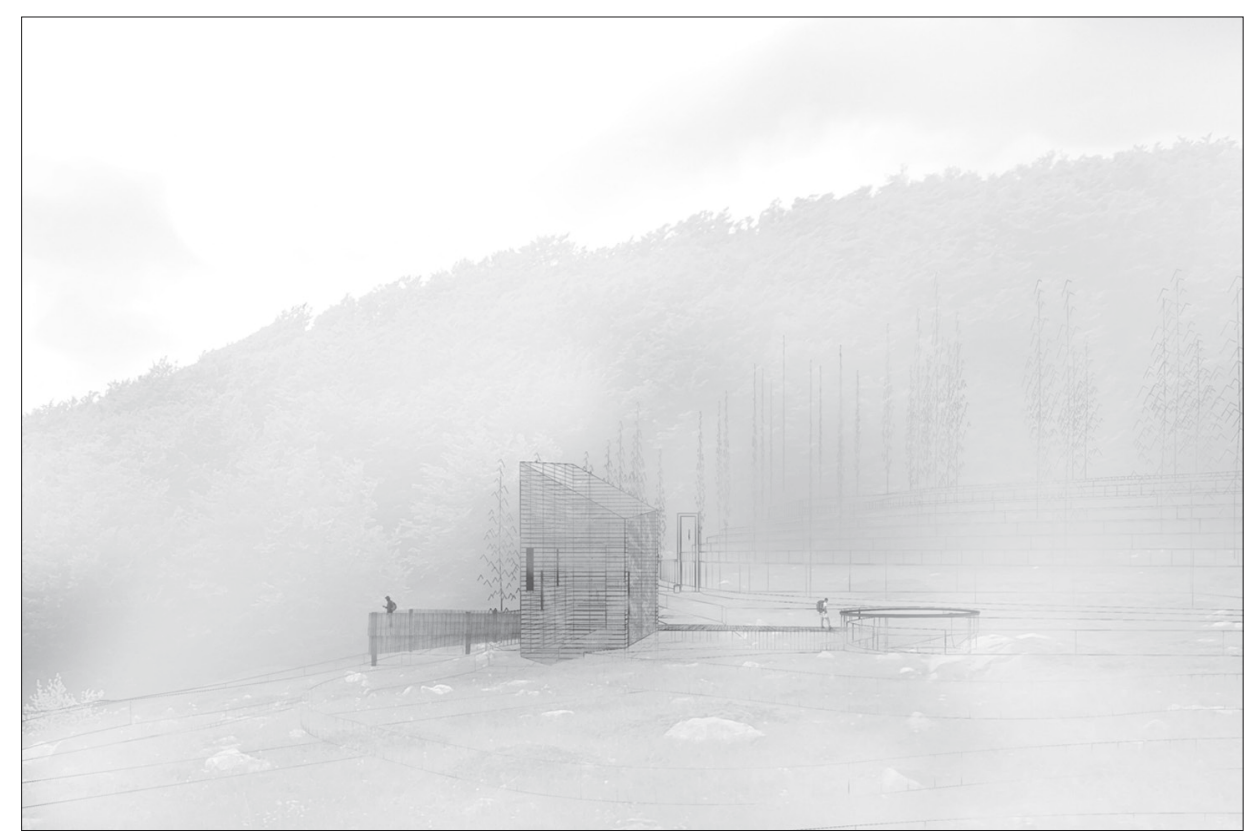

S1. 3. 3D prikaz eksterijera - pristup kapelici, izradila Martina Stjepandić

Krajnji dio narteksa konzolno prolazi kroz obruč drvene ograde kružnog oblika koja lebdi nad vrtačom, udubljenjem u tlu unutar kojeg se sakuplja snijeg, pružajući izvor svježe vode tijekom cijele godine. Krug je koji lebdi nad vodom djelomično oslonjen na prirodni kamen, dok je drugi dio pridržavan vertikalnom konstrukcijom nosača. Otvorena konstrukcija mosta, koji blago naliježe na prirodni teren, ulazna je platforma na koju se kapela svojim malim drvenim ulaznim elementom veže, pozivajući u zatvoreni i zaštićeni prostor unutrašnjosti.

Narteks je istovremeno platforma za fotografski kadar usmjeren prema tihoj zoni nekadašnjega ljetnog pašnjaka, prostor smirivanja duha i kontemplacije u prirodi i s prirodom, ali i priprema za ulazak u kapelicu. U osi kapele blagim se usponom po prirodnom terenu pristupa zvoniku koji je dislociran i stvara vlastitu zvučnu mikrozonu u neposrednoj blizini šume. Vertikalu zvonika tangira horizontala klupe, prostorne točke za stacioniranje koja je vizualno usmjerena prema Mirovu. Time je tipična koncepcija dominantne vertikale zvonika kod crkava položena u horizontalu, a dosadašnja vertikala postaje prirodni teren. Prisutan je i dalje koncept penjati se na zvonik. Zvonik je u ovom slučaju pristupačan svakome tko se poželi oglasiti ili zazvoniti. 


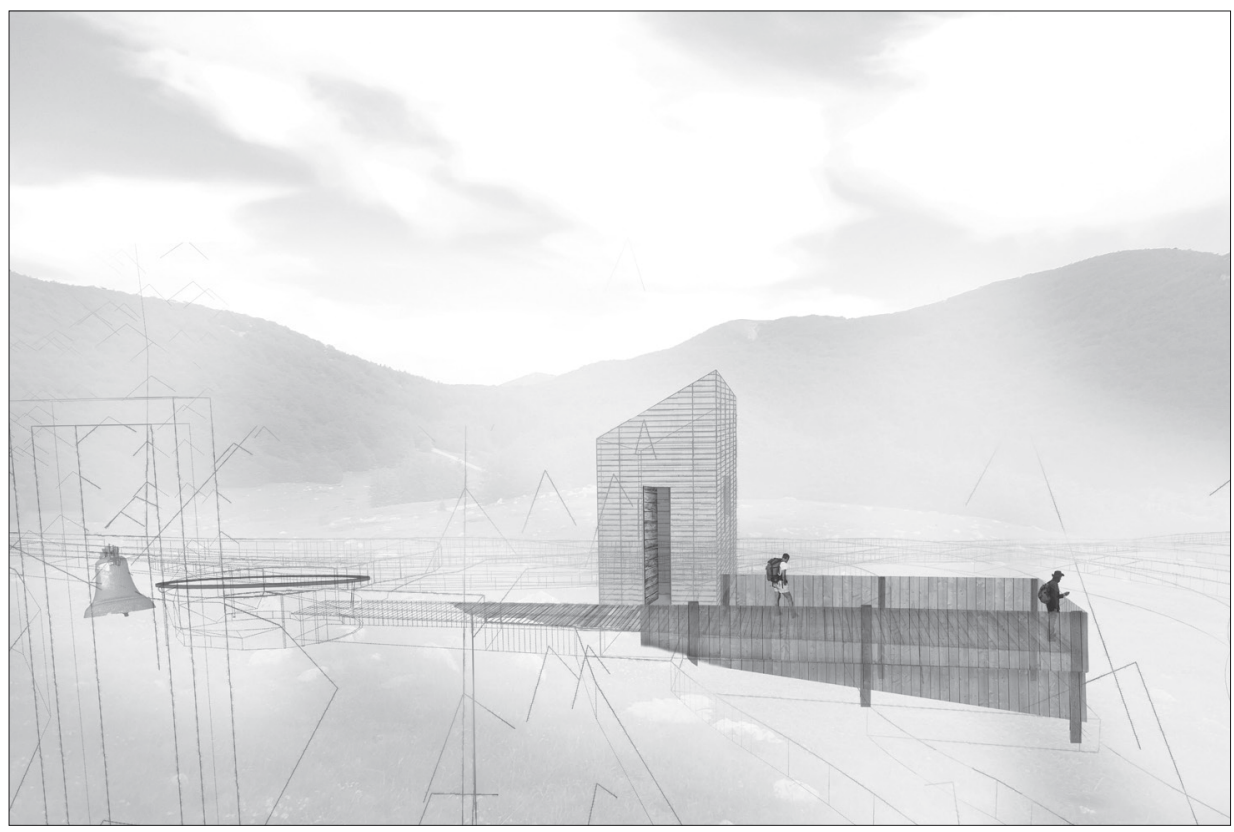

Sl. 4. 3D prikaz eksterijera od zvonika prema ulazu, izradila Martina Stjepandić

Uvjeti izgradnje na Velebitu, na visini od 1400 metara nadmorske visine, sve su samo ne tipični za današnji pristup tehnologiji građenja. Upravo ti rubni, granični uvjeti postavljaju početne premise za rješenja konstrukcije kapelice. Osim aspekta pristupačnosti, prisutan je i aspekt održivosti, u smislu svjesnosti o trajnosti i propadanju materijala kroz neko dulje vrijeme.

Naglasak se daje betonu i drvetu, koji su primarni materijali. Beton kao suvremeni kamen dominira eksterijerom kapelice. Kapela je stoga sama konstruktivno izražena kao veliki betonski masiv visok u prosjeku 8 metara. Budući da je teren u blagom padu, južni dio betonske konstrukcije ostaje lebdjeti nad terenom. Veća debljina zida osigurava njezinu trajnost neovisno o vremenskim uvjetima u kojima se nalazi. Sjeverni zid čini sastav betona $\mathrm{s}$ krupnijim agregatom izvođen in situ. Taj atipični zrnati beton osigurava prirodno stanište flori i fauni Velebita te se očekuje kako će s vremenom postati zelen i obrastao mahovinom poput velebitskog kamena.

Prostor je kapele poluotvoren te je ispod njezine drvene podne konstrukcije tlo vanjskog terena. Unutar betonskog korpusa nalazi se drvena konstrukcija od smreke koja čini pod i bočni zid. Beton je time prostorno obgrlio drvo koje prostoru daje potrebnu toplinu. U centralnoj se osi kapele nalazi veliki križ od 


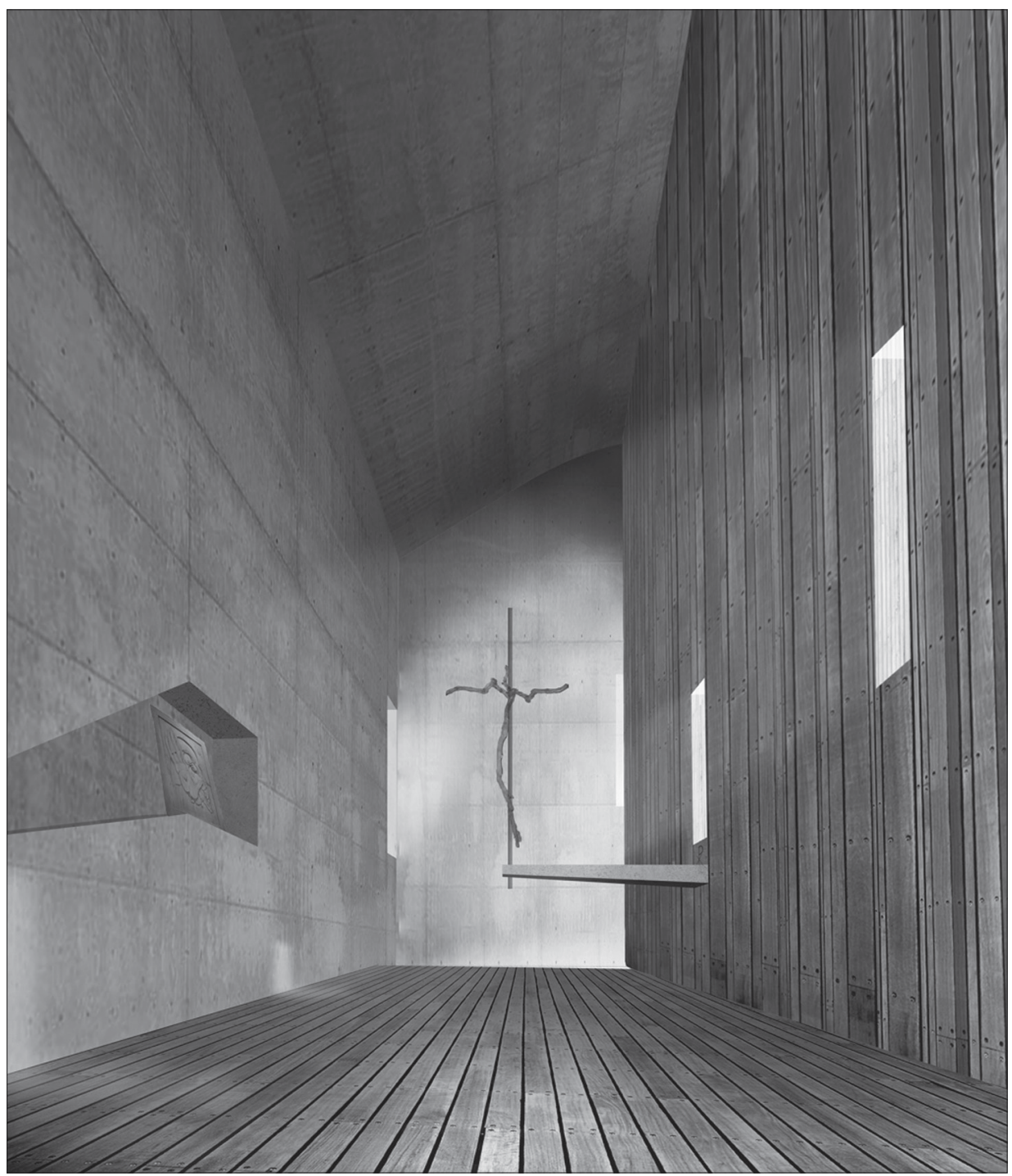

S1. 5. 3D prikaz interijera prema oltaru, autorica: Martina Stjepandić

drveta loze spajanog žicama koji, osim što zaokružuje prirodnost interijera, također oslikava čovjekov život, uključno sa specifičnostima velebitskog načina života - borbu, trud, izmučenost, nepravocrtnost, ali i plodove (rada, truda, borbe), pobjede, kontinuitet i ustrajnost - složena jednostavnost u kojoj je neizostavna duhovna dimenzija. 


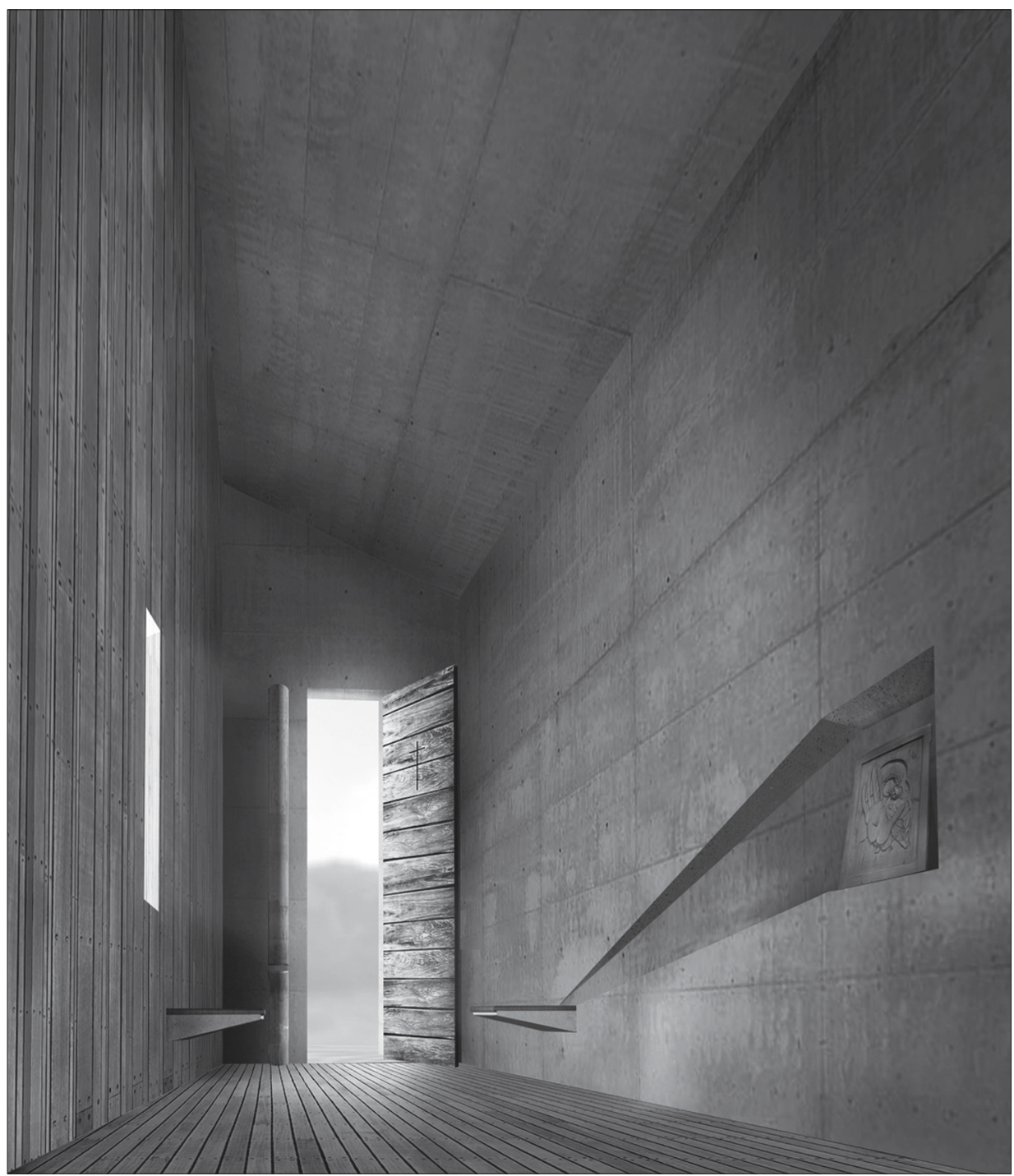

Sl. 6. 3D prikaz interijera - pogled prema ulazu u kapelicu, autorica: Martina Stjepandić

Daske su na nosivim podnim gredama posebno oblikovane tako da omogućuju prodor svjetlosti i kroz spojne reške, dok je bočni zid kontrast podu - dvostruko letvan smrekinim daskama kako bi se onemogućio pogled na betonsku konstrukciju. Time se daje naglasak na otvore, svojevrsne kadrove prema izvoru svjetlosti - prozoru. Otvore ispunjava niz međusobno lijepljenih 
stakalaca koja lome svjetlosne zrake i čine svjetlost difuznom te se spriječava vizualni kontakt s vanjskim prostorom čime je ostvarena željena mističnost $\mathrm{i}$ introvertiranost prostora, $\mathrm{tj}$. usmjerenost na unutrašnjost same kapele. Velebitska kapela time postaje i ostaje svakodnevno utočište u svim vremenskim prilikama i neprilikama.

\section{Zaključak}

Nemoguće je izići iz vremena, no ono što treba učiniti mogućim jest ukomponirati prošlo vrijeme u sadašnje i zajedno ih protegnuti u neke nove sadašnjosti, često nazivane budućnošću. Razumjeti Velebit i njegove žitelje bez njihove zajedničke prošlosti, naprosto je nemoguće ukoliko težimo jednom holističkom pristupu sa što manje negativnih eksternalija, a što više pozitivnih ishoda. Oživjeti, revitalizirati jedan prostor ne znači samo usmjeriti se na vrijednosti vremena $u$ kojem se to oživljenje pokušava ostvariti, već inkomporirati i vrijednosti, a posebno vrjednote koje predstavljaju kamen temeljac toga oživljenja.

Revitalizacija, u širem smislu riječi, podrazumijeva prvenstveno revitalizaciju naše svijesti, edukaciju o vrijednostima i vrednotama koje imamo, kako bismo kroz projekte omogućili indirektni ciklični razvoj ekonomije, pravilno gospodarenje prostorom, daljnji kontrolirani razvoj infrastrukture i dr.

Uspješnost revitalizacije područja Mirova na gore navedeni način nije moguće u potpunosti ustvrditi bez same realizacije projekta. Ipak, već je i na idejnoj razini moguće uočiti inherentan mu pristup koji stavlja naglasak na tradiciju, na prošlost, kao zalog za sadašnjost i budućnost, kao svojevrsni memento onome što je bilo, što jest i što može biti. Istina je, svakako, da ovaj prijedlog već kao ideja odjekuje poput prave velebitske jeke, predstavljajući alternativu dosadašnjim, $k^{\prime}$ o po špranci izloženim prijedlozima za nužni razvoj turizma, ulaganje u ugostiteljstvo, povećanje smještajnih kapaciteta i sl.

U lipnju 2016. godine, projekt Kapelica od Mirova prikazan je u prestižnom internacionalnom arhitektonskom časopisu Domus, gdje je u napomeni dodatno istaknut Velebit - najdulji planinski masiv u zemlji ${ }^{10}$. Ohrabrujuće je vidjeti da projekti koji ne služe isključivo u komercijalne svrhe uspijevaju pridobiti pažnju struke i javnosti, a samim se time afirmira i holistički pristup i društveni angažman arhitekata i arhitekture.

${ }^{10}$ B. KORUŽNJAK, 2016, 14. 
Iako je tek skromni prijedlog male kapele, kapelice, možda upravo ovaj maleni zahvat može biti veliki poticaj za daljnje prijeko potrebne promjene usmjerene na nastanak i nastavak, a ne nestanak života, kulture i tradicije koje ovo velebiće i njegovi preostali velebni stanovnici itekako zaslužuju.

\section{Literatura}

Šime BALEN, Velebit se nadvio nad more, Zagreb, 1999.

Aleksandra FABER, Mirovo - srednji Velebit od jablanačkog limesa do vlake Marije Terezije, Senjski zbornik, 40, Senj, 2013, 657-684.

Ante GLAVIČIĆ, Prilog istraživanju starohrvatske sakralne arhitekture na primorskim padinama Velebita i Velike Kapele (I), Senjski zbornik, 9, 1982, 91-114.

Helena KNIFIĆ SCHAPS, Tradicijska arhitektura Velebita: gradnja koju je proizvela svrha, Hrvatska revija, 1, Zagreb, 2014, online izdanje.

http://www.matica.hr/hr/410/Tradicijska\%20arhitektura\%20Velebita:\%20gradnja\%20 koju\%20je\%20proizvela\%20svrha/ (pregledano 22.12.2016.)

Helena KNIFIĆ SCHAPS, Velebit arhitektonski. Pučka gradnja u dijelovima Sjevernog i Srednjeg Velebita, Zagreb, 2013.

Boris KORUŽNJAK, Facoltà d'architettura dell'Università di Zagabria, Domus, 1003, Milano, 2016, 10-15.

\section{A CONTRIBUTION TO THE REVITALISATION OF MIROVO - A PROPOSAL FOR THE CONSTRUCTION OF A NEW LITTLE CHAPEL}

\section{Summary}

By problematizing the question of the revitalisation of the Velebit region, the author presents the Kapelica of Mirovo project - a project located in the area of central Velebit, right near the locality of Mirovo, which is not an end in itself but is the product of research and a deep connection with Velebit, which in the end have resulted in the conceptual solution which takes into consideration elements of the past, tradition, contemporaneity, yet also anticipates the future - with the aim of the repeated rapprochement of man and the mountain, as well as man and man, and man and his transcendence. At the same time he not only uses an architectural approach but also advocates a comprehensive and interdisciplinary approach to the solution of the problem of revitalisation, which puts the emphasis on the preservation of the tradition and authenticity of Velebit and the Velebit way of life. chapel

Keywords: Mirovo, Velebit, dwellings, revitalisation, architecture, sacral architecture, little 